\title{
TYPOLOGY OF FUNCTIONAL STYLES OF THE BULGARIAN LANGUAGE: CULTURAL, HISTORICAL AND LINGUISTIC ASPECTS
}

\author{
(C) Yulia A. Petrova \\ Rostov State University of Economics, Rostov-on-Don, Russian Federation \\ science-almanac@mail.ru
}

\begin{abstract}
The scientific and technological revolution of the past and present centuries causes global changes, contributes to the interconnection of continents, countries and people. Citizens overcome national, social and linguistic differences. Studying languages, we get to know the world and create our own linguistic worlds, and already through them we learn a lot about the linguistic picture of the world as a whole. The Bulgarian language is considered as one of the languages of the large family of Slavic languages, which are part of the Indo-European languages. Like any other language, Bulgarian is a historical phenomenon. It emerged as an independent language with its own typical and distinctive features at a certain stage in the development of dialects of Slavic tribes. During its centuries-old existence, the Bulgarian language has undergone significant development. The origin of the Bulgarian language can be found in the distant past, and its gradual development continued over the centuries. In its development, there were no sharp leaps and transitions from one quality to another, which is considered in our study.
\end{abstract}

Key words: Bulgarian language, dialect, lexical and grammatical units, typology of styles, isogloss.

\section{[Ю.А. Петрова Типология функциональных стилей болгарского языка: культурно- исторический и лингвистический аспекты]}

Научно-техническая революция прошлого и нынешнего веков вызывает глобальные изменений, способствует взаимосвязи континентов, стран и людей. Граждане преодолевают национальные, социальные и языковые различия. Изучая языки, мы познаем мир и создаем свои собственные языковые миры, и уже через них узнаем много нового о языковой картине миры в целом. Рассмотрен болгарский язык как один из языков большой семьи славянских языков, являющихся частью индоевропейских языков. Как и любой другой язык, болгарский - историческое явление. Он возник как самостоятельный язык со своими типичными и отличительными чертами на определенном этапе развития диалектов славянских племен. За многовековое существование болгарский язык претерпел заметное развитие. Происхождение болгарского языка можно найти в далеком прошлом, и его постепенное развитие продолжалось на протяжении многих веков. В его развитии не было резких скачков и переходов от одного качества к другому, что и рассмотрено в нашем исследовании.

Ключевые слова: болгарский язык, диалект, лексические и грамматические единицы, типология стилей, изоглосс.

Yulia A. Petrova - Ph.D. in Philosophy, Associate Professor, Rostov State University of Economics, Rostovon-Don, Russian Federation.

Петрова Юлия Андреевна - кандидат фрилософрских наук, доцент, Ростовский государственный экономический университет, е. Ростов-на-Дону, Российская Федерация.

One of the features of the Bulgarian language is the stability of its grammatical structure. Its main vocabulary is also distinguished by such stability. The vocabulary components of the primary language change very slowly. The fastest are changes in general vocabulary, i.e. vocabulary because it reflects the cultural and historical changes of a particular people. In the Bulgarian language, the influence of foreign languages can be easily traced, including as a result of cultural linguistic contact. Because "cultures are dynamic and changeable, and no culture is isolated from the influence of other cultures. All cultures 
assimilate elements of other cultures and languages, they expand, adapt and adjust accordingly. Cultural mixing and linguistic hybridization took place throughout the history of mankind [3, pp. 50-57].

The most widespread Slavic languages are: Russian, Ukrainian, Belarusian - in the east; Czech, Slovak Polish - in the west; languages of the former Yugoslavia (Slovenian, Serbo-Croatian, Macedonian) and also Bulgarian - in the south. If we look at the map, we will see the area north of the Black Sea, a vast territory of the steppe land, the place of the ethnogenesis of the southern Slavs.

Slavic languages today have significant differences from each other and similarities with each other. The differences and similarities are based on historical events that not only influenced the development of languages, but also led to lexical and semantic changes.

We know from history that the inter-tribal union of Slavic and Turkic tribes formed the basis of the now unified country of Bulgaria. Despite the fact that Roma, Macedonians, Armenians, Tatars, Romanians, Greeks, Russians and Turks live in Bulgaria, who constitute the largest minority, the ethnic population of the country is considered homogeneous, $4 / 5$ of the total population are Bulgarians.

The Bulgarian language, along with Serbo-Croatian and Slovenian, belongs to the South Slavic group. The Macedonian language has a close connection with Bulgarian; a number of dialects are preserved in both languages. Bulgarian is the official language of the country, and for over $80 \%$ of the population of Bulgaria is the mother tongue. Bulgaria is a small country with an area of $110,910 \mathrm{sq}$. $\mathrm{km}$. located along the Black Sea coast. The population of Bulgaria is 6948445 people (UN data as of 01.07.2020) [10]. Bulgaria can also be called a "young" country because independent kingdom of Bulgaria proclaimed itself in 1908. Despite the small territory of the country, not great age and not large population "Bulgaria is rich historically, culturally, geographically and linguistically" [7, p.5].

In the article "The Bulgarian language" K. Kuiper divides the history of the Bulgarian language into three periods: 1 . Old Bulgarian (for those who hold the opinion that the Old Slavonic language is based on the Old Bulgarian) of the $9^{\text {th }}-11^{\text {th }}$ centuries. 2 . Middle Bulgarian $12^{\text {th }}-16^{\text {th }}$ and 3 . Modern Bulgarian from the $16^{\text {th }}$ century to the present day [11].

The Old Bulgarian period is associated with the adoption of Christianity in the 9th century and the construction of the Old Bulgarian language. Then borrowings were of a religious nature, the lexicon included such words as angel, icon, "manastir" - "monastery", etc. During this period, most of the names of people that exist at the present time were also included: Stephen, Georgi, Peter, etc.

In the Middle Bulgarian period, both Greek and Turkish influence is very significant. The influence of the Greek Empire lasted until the 14th century, as evidenced by such words as magdanoz - parsley, major - hand of the master, livada - meadow, names of school subjects: geography, physics, morphology', etc. Loss of cases in the noun, as well as many other linguistic changes took place in the Middle Bulgarian period, which began with the conquest of Bulgaria. Turkish borrowings in the Bulgarian language date back to the reign of the Ottoman Empire, the imposition of the Turkish language and oriental culture, and the settlement of Turks in some areas contributed to the spread and strengthening of the influence of the Turkish language and culture on the Bulgarians. This influence is evidenced by the names in the Turkish language of settlements, squares, streets. Also, the vocabulary includes a lot of Turkish words, in the field of crop production, animal husbandry, trade, craft and folklore vocabulary. It was difficult to exclude them from the vocabulary because they completely replaced their Bulgarian equivalents. Some of these words are still used today.

Turcisms have a phonetic structure that usually does not differ from the original Turkish words. However, there is also a phonetic change, which is the result, on the one 
hand, of adaptation to the phonetic system of the Bulgarian language and its dialects, and on the other hand, the source of their borrowing is not only Ottoman Turkish, but also Turkish dialects. Thus, the phonetics of Turkish borrowings should be considered not only in the context of phonetic adaptation, but also in the context of certain trends affecting Turkish words in their original environment, or rather in the Rumelian dialect of the Turkish language [6, p. 41-45].

Compared to Turkish nouns, the number of verbs and adjectives used in the Bulgarian language is significantly small. As for the Turkish nouns included in the Bulgarian language, it should be noted that there are three genders in the Bulgarian language: masculine, feminine and neuter; in Turkish there is no genus. Turkish nouns in Bulgarian have been given the corresponding gender depending on their endings. If they end in a consonant, they become masculine nouns, and if they end in a vowel, they are either feminine or neuter. As for Turkish adjectives, most of them have remained unchanged and do not have gender markers. Only in a few rare cases, when the ending of a Turkish adjective coincided with a Bulgarian suffix, did it acquire all the features of the Bulgarian adjective. Thus, only a small part of adjectives received Slavic suffixes and, thus, completely entered the system of Bulgarian adjectives.

Linguistically, the borrowings also included numerous metaphors, comparisons, epithets, and interjections. Culturally, the influence of Turkism was reflected in the field of folklore, folk poetry and musical and songwriting, song melodies, which are "a stable form of reproduction of cultural traditions, more precisely the stereotypes of behavior and communication existing in culture" [2, p. 122].

The poetic device of the Bulgarian folklore is the use of "synonymous pairs", which are a combination of words, one of which has been preserved in the original lexical meaning of the Bulgarian language with a synonym itself borrowed in Turkish or Greek.

On the one hand, such a phrase gives expressiveness and, on the other hand, eliminates the monotony of the narrative. Turkish folklore of the Ottoman Empire and Slavic folk poetry includes numerous elements acquired as a result of long-term contacts between the two peoples. This is evidenced by the poetic size, and the genre, and the rhythmic-melodic structure of the music and, in part, the musical instruments themselves. These elements of the Turkish language were borrowed by the Bulgarian language and introduced into poetry and music a characteristic "oriental" flavor, new musical instruments, various types of songs, dances and musical terminology [4].

The third period, Modern Bulgarian is characterized by a significant content in the vocabulary of the Bulgarian language of Russian and Church Slavonic borrowings, although the purist movement in the period between the First and Second World Wars tried to replace these words with native Bulgarian, it was not possible to significantly reduce the number of borrowings in the modern Bulgarian language. It should be noted that the intensity and scale of borrowings were not always the same. The degree of influence of the Russian language was determined not only by cultural and historical reasons, but also by the significant similarity between Russian and Bulgarian. The modern Bulgarian script, derived from the language of religious assemblies of the 16th century, was not formed until the $19^{\text {th }}$ century. Russian words remained in the Bulgarian lexicon mainly in the terminology of the socio-political, administrative, military, literary, scientific and technical fields [8].

The study of the national "semantic space of the language, as well as systemic relations in the language", make it possible to interpret the linguocognitive concept "in the context of the linguoculturological approach" [1, pp. 159-165]. The period that the Bulgarian language is experiencing in our time, like all Slavic linguistics as a whole, can be compared with the Renaissance period from the point of view of linguistic typology, its state provides for intensive development. Today, in all Slavic countries, intensive work is underway to create dialectological atlases of various types. In 2005, the Oxford University Press 
published the First version of the World Atlas of Language Structures (WALS), the first online version appeared in April 2008.

Linguistic maps mean thousands of languages on maps of 5 continents: Africa, America, Asia, Europe, Oceania and Antarctica. They provide an opportunity to see what neither monographs nor dictionaries can open. They make it possible to identify the spatial localization of interlingual similarities and differences and what is equally important to evaluate them from the areal and historical point of view. However, it should be recognized that the linguistic map is difficult to understand. In order to understand it, one must learn to read the map, catch the patterns in its organization.

Linguistics, thanks to linguistic geography, has been enriched with new research tools i.e., linguistic mapping of phonetic, lexical and grammatical features. "Spatial discourse, together with the description of the structure and function of linguistic units in synchronicity and diachrony, created a kind of epistemological trinity of linguistics of the 21st century, which explores language" in three dimensions: space, time and structure. And in this changing paradigm of modern linguistics a huge role belongs to the Project "Common Slavic Linguistic Atlas", the maps of which made it possible to visually represent all the diversity of the dialectal landscape, including Bulgaria [5].

The archive of the Bulgarian Dialectical Atlas includes dialectal material from 2,400 villages located throughout the linguistic territory, both within and outside Bulgaria. 470 researchers took part in the dialectological expeditions, including teachers and students of the Department of Bulgarian Dialectology and Linguistic Geography of the Sofia University. For example, 1450 index maps were created from authentic material of folk speech (from special questionnaires). This unique archive with authentic material, collected over many years, preserves the living folk speech, which makes it unique not only nationally, but also internationally, as it comprehensively studies dialects. This material is of interest to dialectologists, philosophers, linguists, language historians, ethnologists and other researchers [9].

\section{Лumepamypa}

1. Петрова Ю.А. Особенности лингвокультурогического подхода к исследованию ценностей молодежной субкультуры // Экономические и гуманитарные исследования регионов. 2012. № 3. С. 159-165.

2. Петрова Ю.А. Репрезентация ценностей молодежной субкультуры в ценностно-смысловом пространстве языка. Дисс. канд. фрилос. наук. Ростов-на-Дону, 2012, 189 c.

3. Петрова Ю.А. Многокультурность и межкультурность, культура и язык в XXI веке // Гуманитарные и социальные науки. 2019. № 4. С. 50-57.

4. Ужинин E.E. Турецкие заимствования в языках восточно-средиземноморского ареала. Автореф. дис. канд. филол. наук. М., 2008.

5. Dryer Matthew S. \& Haspelmath, M. (eds.) The World Atlas of Language Structures Online. Leipzig: Max Planck Institute for Evolutionary Anthropology, 2013.

6. Jordanian Georgheva-Okon Borrowings in Bulgarian dialects. Vowels, Management and Education, Vol. 2, 2011, pp. 41-45.

7. Leafgren J. A Concise Bulgarian. Grammar. Publisher: SEELRC, 2011, p.5, p.84.

8. Sakareva I. Changes in the Bulgarian Language during the Centuries: Impact of Different Cultures on the Language in the Past. In: TRANS. Internet-Zeitschrift für Kulturwissenschaften, No. 16, 2005.

9. [Электронный ресурc], URL: https://ibl.bas.bg/en/drugi (дата обращения 01.11.2020).

10. [Электронный ресурc], URL: https://worldpopulationreview.com/countries/bulgari (дата обращения 27.10.2020). 
11. [Электронный ресурc], URL: https://www.britannica.com/topic/Bulgarian-language, October, 2020(2016) (дата обращения 30.10.2020).

\section{References}

1. Kandova Ya. Zaimstvovaniya v bolgarskom yazyke [Borrowings in the Bulgarian language]. Novaya Literatura. 02, 2017, Available at: http://newlit.ru/sale/2017_02.html, (accessed 10.08.2020) (In Russian).

2. Petrova Yu.A. Osobennosti lingvokulturogicheskogo podkhoda $\mathrm{k}$ issledovaniyu tsennostey molodezhnoy subkultury [Features of the linguocultural approach to the study of the values of youth subculture]. Ekonomicheskiye i gumanitarnyye issledovaniya regionov. 2012. No. 3. pp. 159-165 (In Russian).

3. Petrova Yu.A. Reprezentatsiya tsennostey molodezhnoy subkultury $v$ tsennostnosmyslovom prostranstve yazyka. Diss. kand. filos. nauk [Representation of the values of the youth subculture in the value-semantic space of the language. Dissertation of the candidate of philosophical sciences]. Rostov-na-Donu, 2012. 189 p. (In Russian).

4. Petrova Yu.A. Mnogokulturnost i mezhkulturnost, kultura i yazyk v XXI veke [Multiculturalism and interculturality, culture and language in the $21^{\text {st }}$ century]. Gumanitarnyye i sotsialnyye nauki. 2019. No. 4. pp. 50-57 (In Russian).

5. Uzhinin Ye.Ye. Turetskiye zaimstvovaniya $v$ yazykakh vostochnosredizemnomorskogo are-ala. Avtoref. dis. kand. filol. nauk [Turkish loanwords in the languages of the Eastern Mediterranean areal. Abstract of the dissertation of the candidate of philological sciences]. Moscow. 2008 (In Russian).

6. Dryer Matthew S. \& Haspelmath, M. (eds.) The World Atlas of Language Structures Online. Leipzig: Max Planck Institute for Evolutionary Anthropology, 2013.

7. Jordanian Georgheva-Okon Borrowings in Bulgarian dialects. Vowels, Management and Education, Vol. 2, 2011, pp. 41-45.

8. Leafgren J.A Concise Bulgarian. Grammar. Publisher: SEELRC. 2011. 84 p.

9. Sakareva I. Changes in the Bulgarian Language during the Centuries: Impact of Different Cultures on the Language in the Past. In: TRANS. Internet-Zeitschrift für Kulturwissenschaften, No. 16, 2005.

10. Available at: https://ibl.bas.bg/en/drugi, (accessed 01 November 2020) (In Russian).

11. Available at: https://worldpopulationreview.com/countries/bulgari, (accessed 27 October 2020) (In Russian).

12. Available at: https://www.britannica.com/topic/Bulgarian-language, October, 2020(2016), (accessed 30 October 2020) (In Russian). 